\title{
Tuliposides H-J and Bioactive Components from the Bulb of Amana edulis
}

\author{
Chia-Lin Lee ${ }^{1,2,3, *(0)}$, Zhi-An Gao ${ }^{1}$, Yun-Lian Jhan ${ }^{1}$, Yuan-Shiun Chang ${ }^{4}$ and Chao-Jung Chen ${ }^{5,6}$ \\ 1 Department of Cosmeceutics, China Medical University, Taichung 406040, Taiwan; \\ s10061131@gmail.com (Z.-A.G.); u9884002@cmu.edu.tw (Y.-L.J.) \\ 2 Chinese Medicine Research and Development Center, China Medical University Hospital, \\ Taichung 40402, Taiwan \\ 3 Chinese Medicine Research Center, China Medical University, Taichung 40402, Taiwan \\ 4 Department of Chinese Pharmaceutical Sciences and Chinese Medicine Resources, China Medical University, \\ Taichung 40402, Taiwan; yschang@mail.cmu.edu.tw \\ 5 Graduate Institute of Integrated Medicine, China Medical University, Taichung 40402, Taiwan; \\ ironmanchen@yahoo.com.tw \\ 6 Proteomics Core Laboratory, Department of Medical Research, China Medical University Hospital, \\ Taichung 40402, Taiwan \\ * Correspondence: chlilee@mail.cmu.edu.tw; Tel.: +886-4-2205-3366 (ext. 5806)
}

Citation: Lee, C.-L.; Gao, Z.-A.; Jhan,

Y.-L.; Chang, Y.-S.; Chen, C.-J.

Tuliposides H-J and Bioactive

Components from the Bulb of Amana

edulis. Molecules 2021, 26, 5907.

https://doi.org/10.3390/

molecules 26195907

Academic Editor: Andrea Penoni

Received: 17 September 2021

Accepted: 27 September 2021

Published: 29 September 2021

Publisher's Note: MDPI stays neutral with regard to jurisdictional claims in published maps and institutional affiliations.

Copyright: (c) 2021 by the authors. Licensee MDPI, Basel, Switzerland. This article is an open access article distributed under the terms and conditions of the Creative Commons Attribution (CC BY) license (https:// creativecommons.org/licenses/by/ $4.0 /)$.

\begin{abstract}
Three new tuliposides H-J (1-3) and 11 known compounds were obtained from the methanolic extracts of the bulbs of Amana edulis for the first time. Their structures were elucidated by NMR, MS, and IR spectroscopic data, optical rotation, and Mosher's method. The melanogenesis properties of all the isolates were evaluated in B16 melanoma cells. Consequently, tributyl citrate (9) had anti-melanogenesis activity but was cytotoxic toward B16. (+)-Pyroglutamic acid (4), (+)-butyl 5-oxopyrrolidine-2-carboxylate (6), (-)-3-hydroxy-2-methylbutyrolactone (10), and 5(hydroxymethyl)furfural (12) had increased melanin productions and tyrosinase activities. Those active components could be further studied as the candidates against melanoma and vitiligo for skin diseases or whitening/hypopigmentation for hair.
\end{abstract}

Keywords: Amana edulis; Liliaceae; bulb; tuliposides H-J; melanogenesis regulation

\section{Introduction}

Amana edulis (A. edulis; Miq.) Honda, syn. Tulipa edulis (Miq.) Baker belongs to the Liliaceae family and is a folk medicinal plant used to treat cancer diseases [1,2]. However, there have been few phytochemical and biological studies of this species reported to date. For example, 95\% and 50\% EtOH extracts could induce apoptosis in human gastric (SGC7901) [1] and hepatoma (BEL7404, HepG2, and Huh7) [2] carcinoma cells, respectively. The polysaccharides prepared from $A$. edulis have anti-oxidant properties, including $\mathrm{DPPH}$, $\mathrm{OH}^{-}$, and $\mathrm{ABTS}^{+}$scavenging activities [3-5]. In a research of new agents from natural products for skin disorders, we found that the $\mathrm{MeOH}$ extracts of the bulbs of $A$. edulis show potential melanogenesis regulation that has not yet been researched. When exposed to the ultraviolet radiation of solar light or harmful chemicals and pathogenic factors, moderate melanogenesis can protect our skin from reactive oxygen species generation in keratinocytes and melanocytes [6]. Tyrosinase is an important enzyme in melanogenesis to produce more melanin for us to defense against aforementioned hazardous conditions [7]. Therefore, the active components of $A$. edulis are worthy to be clarified for further medical applications. In this investigation, three new tuliposides $\mathrm{H}-\mathrm{J}$ (1-3) and 11 known compounds (4-14) (Figure 1) were isolated from A. edulis and structurally identified by NMR, MS, and IR spectroscopic data, optical rotation, or Mosher ester reaction. Compound 9 could decrease melanin contents but be cytotoxic toward B16 melanoma cells. Compounds $4,6,10$, and 12 had increased melanin productions and tyrosinase activities. Overall, this 
work proved A. edulis and its active components could be new agents for melanin-related diseases, such as melanoma and hypopigmentation (skin vitiligo or hair whitening).

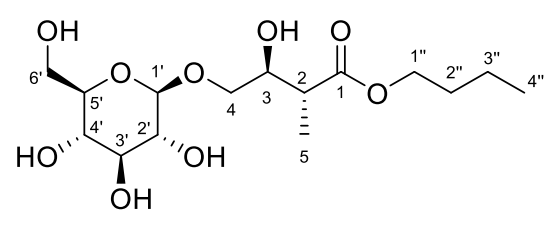

1<smiles>O=C1CCC(C(=O)O)N1</smiles>

$4 \mathrm{R}=\mathrm{H}$

$5 \mathrm{R}=\mathrm{CH}_{3}$

$6 \mathrm{R}=\mathrm{CH}_{2} \mathrm{CH}_{2} \mathrm{CH}_{2} \mathrm{CH}_{3}$<smiles>CCCCOC(=O)[C@H](C)CCO[C@H]1O[C@H](CO)[C@@H](O)[C@H](O)[C@H]1O</smiles>

2<smiles>C[C@H]1C(=O)OC[C@@H]1O</smiles>

10<smiles>C[C@H](CCOC1OC(CO)[C@H](O)C(O)C1O)C(=O)O</smiles>

3<smiles>COC(=O)C1(O)COC(=O)C1</smiles>

11<smiles>O=Cc1ccc(CO)o1</smiles>

12<smiles>CCCCCOC(=O)CC(O)(CC(=O)OCC)C(=O)OC</smiles>

$7 \mathrm{R}_{1}=\mathrm{R}_{2}=\mathrm{H}$

$8 \mathrm{R}_{1}=\mathrm{CH}_{2} \mathrm{CH}_{2} \mathrm{CH}_{2} \mathrm{CH}_{3}, \mathrm{R}_{2}=\mathrm{CH}_{3}$

$9 \mathrm{R}_{1}=\mathrm{R}_{2}=\mathrm{CH}_{2} \mathrm{CH}_{2} \mathrm{CH}_{2} \mathrm{CH}_{3}$<smiles>[R6]C1CCC2(C)C(=CCC3C2CCC2(C)C3CCC2[C@H](C)CCC(CC)C(C)C)C1</smiles>

$13 \mathrm{R}=\mathrm{H}$

$14 R=G I C$

Figure 1. Structures of compounds 1-14.

\section{Results and Discussion}

\subsection{Structure Elucidations of Isolates 1-3}

The $\mathrm{MeOH}$ extract (TEM) of the bulbs of A. edulis was partitioned into EtOAc-soluble (TEE), $n$ - $\mathrm{BuOH}$-soluble (TEB), and $\mathrm{H}_{2} \mathrm{O}$-soluble (TEW) fractions separately. The fractionation of the TEE and TEB extracts afforded new isoprenoid glycosides 1-3 and known compounds 4-14 (Figure 1). Additionally, the major components of the TEW extract were carbohydrates.

The HRESIMS (high-resolution electrospray ionization mass spectrometry) of $\mathbf{1}$ showed a $[\mathrm{M}-\mathrm{H}]^{-}$ion at $m / z 351.1652$, indicating a molecular formula of $\mathrm{C}_{15} \mathrm{H}_{28} \mathrm{O}_{9}$ (calcd for $\left.\mathrm{C}_{15} \mathrm{H}_{27} \mathrm{O}_{9} ; 351.1655\right)$ and two degrees of unsaturation. The IR spectrum showed absorptions for hydroxyl $\left(3376 \mathrm{~cm}^{-1}\right)$ and carbonyl $\left(1725 \mathrm{~cm}^{-1}\right)$ functionalities. Fifteen carbon signals, including two methyls, five methylenes, seven methines, and one quaternary carbon, were observed in the one-dimensional (1D) NMR spectra of 1 (Table 1). The quaternary carbon was identified as a carbonyl carbon on the basis of the chemical shift at $\delta_{\mathrm{C}}$ 176.6. The $1 \mathrm{D}$ and HSQC (heteronuclear single quantum coherence) NMR spectra displayed one anomeric $\left(\delta_{\mathrm{H}} / \delta_{\mathrm{C}}: 4.27(\mathrm{~d}, J=8.0 \mathrm{~Hz}) / 104.9\right)$, five oxymethine $\left(\delta_{\mathrm{H}} / \delta_{\mathrm{C}}: 3.21\right.$ $(\mathrm{t}, J=8.0 \mathrm{~Hz}) / 75.1,3.28$ (overlap)/71.6, 3.28 (overlap)/78.0, $3.35(\mathrm{t}, J=8.0 \mathrm{~Hz}) / 77.9$, and $3.89(\mathrm{td}, J=7.0,2.5 \mathrm{~Hz}) / 73.6)$, and three oxymethylene $\left(\delta_{\mathrm{H}} / \delta_{\mathrm{C}}: 3.57(\mathrm{dd}, J=10.5,7.0 \mathrm{~Hz})\right.$, $4.01(\mathrm{dd}, J=10.5,2.5 \mathrm{~Hz}) / 73.1,3.66(\mathrm{dd}, J=12.0,5.0 \mathrm{~Hz}), 3.85(\mathrm{brd}, J=12.0 \mathrm{~Hz}) / 62.7$, and $4.10(2 \mathrm{H}, \mathrm{t}, J=7.5 \mathrm{~Hz}) / 65.5)$ signals. The HMBC (heteronuclear multiple bond correlation) correlations (Figure 2) of compound 1 at the methine protons $\mathrm{H}-2$ ( $\delta 2.67$, quint) with C-1 $(\delta 176.6) / \mathrm{C}-3(\delta$ 73.6)/C-4 $(\delta 73.1) / \mathrm{C}-5(\delta 13.9), \mathrm{H}-3(\delta 3.89, \mathrm{td})$ with C-1/C-2 $(\delta 44.6) / \mathrm{C}-4 / \mathrm{C}-5, \mathrm{H}_{-1}{ }^{\prime}(\delta 4.27, \mathrm{~d})$ with $\mathrm{C}-4$, and the methyl protons $\mathrm{H}_{3}-5(\delta 1.14$, d) with C-1/C-2/C-3 suggested that the methyl and hydroxyl moieties were positioned at C-2 and $\mathrm{C}-3$, respectively. In addition, the methylene protons at $\mathrm{H}_{2}-1^{\prime \prime}(\delta 4.10, \mathrm{t})$ and $\mathrm{H}_{2}-4(\delta 3.57$, $\mathrm{dd} ; 4.01, \mathrm{dd})$ exhibited ${ }^{3} J$ interactions with C-1 and C-1' ( $\left.\delta 104.9\right)$, respectively, in the HMBC spectrum (Figure 2) that supported the assignments of the $n$-butyl group at $\mathrm{C}-1$ and one beta-glucose $\left(\mathrm{H}_{-1}{ }^{\prime}, \delta 4.27, \mathrm{~d}, J=8.0 \mathrm{~Hz}\right)$ at $\mathrm{C}-4$ [8]. Figure 2 shows key COSY and HMBC correlations observed for 1 . The relative configurations at C-2 and C-3 (3-hydroxy-2-methyl 
moiety) of 1 could be determined anti-form by the ${ }^{3} \mathrm{~J}_{\mathrm{H} 2-\mathrm{H} 3}$ value of $7.0 \mathrm{~Hz}$ (anti-form: $7.0 \mathrm{~Hz}$; syn-form: $4.0 \mathrm{~Hz}$ ) [9]. To determine the absolute configuration, compound 1 was treated separately with $(R)$ - and $(S)$ - $\alpha$-methoxy- $\alpha$-(trifluoromethyl)-phenylacetyl chloride $[(R)$ - and $(S)$-MTPA-Cl] in the presence of pyridine- $d 5$ to obtain the (S)- and (R)-MTPA esters (1a and 1b), respectively. The MTPA esters were generated successfully at $C-3$ and $C-2^{\prime} / C-3^{\prime} / C-4^{\prime}$, as elucidated from the ${ }^{1} \mathrm{H}$ NMR and ${ }^{1} \mathrm{H}-{ }^{1} \mathrm{H}$ COSY spectra $\left(1 \mathbf{a}, \mathrm{H}-3, \delta 5.82, \mathrm{~m} ; \mathrm{H}-2^{\prime}, \delta 5.70, \mathrm{t}\right.$, $J=9.5 \mathrm{~Hz} ; \mathrm{H}-3^{\prime}, \delta 4.39, \mathrm{t}, J=9.5 \mathrm{~Hz} ; \mathrm{H}-4^{\prime}, \delta 5.76, \mathrm{t}, J=9.5 \mathrm{~Hz} ; \mathbf{1 b}, \mathrm{H}-3, \delta 5.81, \mathrm{~m} ; \mathrm{H}-2^{\prime}, \delta 5.56$, $\left.\mathrm{t}, J=9.5 \mathrm{~Hz} ; \mathrm{H}-3^{\prime}, \delta 4.12, \mathrm{t}, J=9.5 \mathrm{~Hz} ; \mathrm{H}-4^{\prime}, \delta 5.66, \mathrm{t}, J=9.5 \mathrm{~Hz}\right)$. The differences between the ${ }^{1} \mathrm{H}$ NMR chemical shifts for $\mathbf{1 a}$ and $\mathbf{1} \mathbf{b}(\Delta$ values shown in Figure 3$)$ led to the assignments of $S$ - and $R$-configurations at C-3 and C-2, respectively. Consequently, compound 1 was elucidated as butyl 4- $\beta$-D-glycopyranosyl-(S)-3-hydroxy-(R)-2-methylbutanoate and named tuliposide $\mathrm{H}$.

Table 1. ${ }^{1} \mathrm{H}$ and ${ }^{13} \mathrm{C}$ NMR spectroscopic data (500 and $125 \mathrm{MHz} ; \mathrm{CD}_{3} \mathrm{OD}$ ) for 1-3.

\begin{tabular}{|c|c|c|c|c|c|c|}
\hline \multirow[b]{2}{*}{ Position } & \multicolumn{2}{|c|}{ Tuliposide H (1) } & \multicolumn{2}{|c|}{ Tuliposide I (2) } & \multicolumn{2}{|c|}{ Tuliposide J (3) } \\
\hline & $\delta_{\mathrm{H}}(J$ in $\mathrm{Hz})$ & $\delta_{\mathrm{C}}$ & $\delta_{\mathbf{H}}(J$ in $\mathbf{H z})$ & $\delta_{\mathrm{C}}$ & $\delta_{\mathrm{H}}(J$ in $\mathrm{Hz})$ & $\delta_{\mathrm{C}}$ \\
\hline \multicolumn{7}{|l|}{ Isoprenoid } \\
\hline 1 & & 176.6 & & 178.5 & & 180.6 \\
\hline 2 & 2.67 (quint, 7.0 ) & 44.6 & 2.63 (sext, 7.0) & 37.8 & 2.63 (sext, 7.0) & 37.6 \\
\hline 3 & $3.89(\mathrm{td}, 7.0,2.5)$ & 73.6 & $\begin{array}{l}1.65 \text { (sext, 7.0) } \\
1.96 \text { (sext, 7.0) }\end{array}$ & 34.6 & $\begin{array}{l}1.68 \text { (sext, 7.0) } \\
2.00 \text { (sext, 7.0) }\end{array}$ & 34.7 \\
\hline 4 & $\begin{array}{l}3.57(\mathrm{dd}, 10.5,7.0) \\
4.01(\mathrm{dd}, 10.5,2.5)\end{array}$ & 73.1 & $\begin{array}{l}3.54(\mathrm{dt}, 10.0,7.0) \\
3.87(\mathrm{dt}, 10.0,7.0)\end{array}$ & 68.4 & $\begin{array}{l}3.61(\mathrm{dt}, 10.0,7.0) \\
3.92(\mathrm{dt}, 10.0,7.0)\end{array}$ & 68.6 \\
\hline 5 & $1.14(\mathrm{~d}, 7.0)$ & 13.9 & $1.12(\mathrm{~d}, 7.0)$ & 17.5 & $1.17(\mathrm{~d}, 7.0)$ & 17.6 \\
\hline \multicolumn{7}{|l|}{ Glc } \\
\hline $1^{\prime}$ & $4.27(\mathrm{~d}, 8.0)$ & 104.9 & $4.19(\mathrm{~d}, 8.0)$ & 104.4 & $4.23(\mathrm{~d}, 8.0)$ & 104.4 \\
\hline $2^{\prime}$ & $3.21(t, 8.0)$ & 75.1 & $3.14(t, 8.0)$ & 75.6 & $3.16(t, 8.0)$ & 75.1 \\
\hline $3^{\prime}$ & $3.35(t, 8.0)$ & 77.9 & $3.30(t, 8.0)$ & 78.0 & $3.34(t, 8.0)$ & 77.9 \\
\hline $4^{\prime}$ & 3.28 (overlap) & 71.6 & 3.22 (overlap) & 71.4 & 3.27 (overlap) & 71.6 \\
\hline $5^{\prime}$ & 3.28 (overlap) & 78.0 & 3.22 (overlap) & 77.8 & 3.27 (overlap) & 78.0 \\
\hline $6^{\prime}$ & $\begin{array}{c}3.66(\mathrm{dd}, 12.0,5.0) \\
3.85(\mathrm{brd}, 12.0)\end{array}$ & 62.7 & $\begin{array}{l}3.62(\mathrm{dd}, 12.0,5.5) \\
3.80(\mathrm{dd}, 12.0,2.0)\end{array}$ & 62.8 & $\begin{array}{c}3.66(\mathrm{dd}, 12.0,5.5) \\
3.85(\mathrm{brd}, 12.0)\end{array}$ & 62.8 \\
\hline \multicolumn{7}{|l|}{$n$-butyl } \\
\hline $1^{\prime \prime}$ & $4.10(2 \mathrm{H}, \mathrm{t}, 7.5)$ & 65.5 & $4.04(2 \mathrm{H}, \mathrm{t}, 7.5)$ & 65.4 & & \\
\hline $2^{\prime \prime}$ & $1.63(2 \mathrm{H}$, quint, 7.5$)$ & 31.8 & $1.57(2 \mathrm{H}$, quint, 7.5$)$ & 31.8 & & \\
\hline $3^{\prime \prime}$ & $1.41(2 \mathrm{H}$, sext, 7.5$)$ & 20.2 & $1.34(2 \mathrm{H}$, sext, 7.5$)$ & 20.2 & & \\
\hline $4^{\prime \prime}$ & $0.94(3 \mathrm{H}, \mathrm{t}, 7.5)$ & 14.0 & $0.90(3 \mathrm{H}, \mathrm{t}, 7.5)$ & 14.0 & & \\
\hline
\end{tabular}

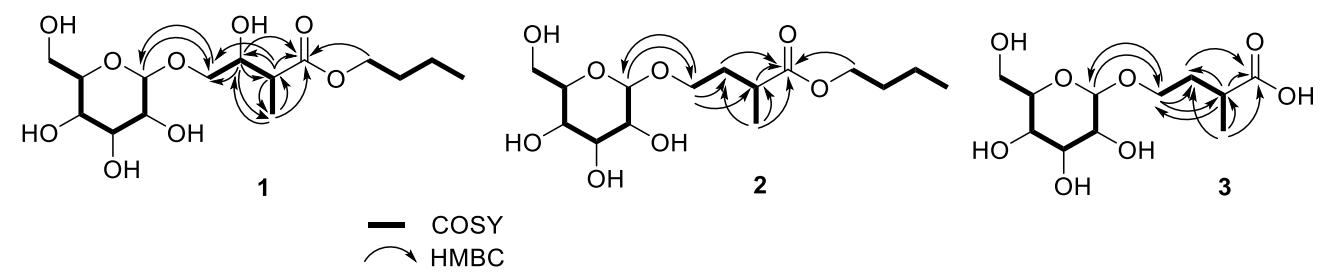

Figure 2. Key COSY and HMBC correlations of compounds 1-3.

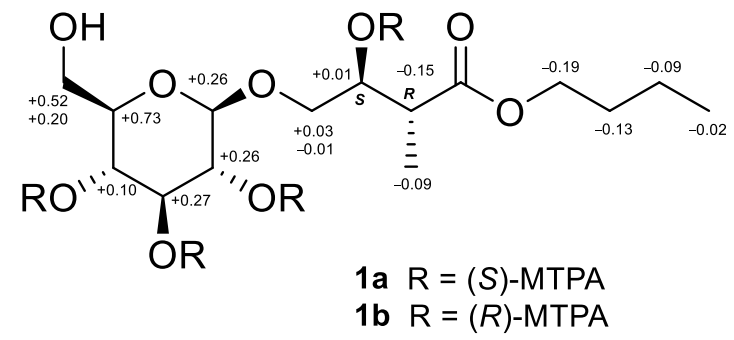

Figure 3. ${ }^{1} \mathrm{H}$ NMR chemical shift differences $[\delta(S)$-MTPA— $\delta(R)$-MTPA] of the MTPA esters $\mathbf{1 a}$ and $\mathbf{1} \mathbf{b}$. 
Compound 2, tuliposide I, gave the molecular formula, $\mathrm{C}_{15} \mathrm{H}_{28} \mathrm{O}_{8}$, as established by HRESIMS $\left(m / z 359.1686[\mathrm{M}+\mathrm{Na}]^{+}\right.$, calcd for 359.1682). The 1D NMR spectra of 2 were also similar to those of $\mathbf{1}$, except the fact that the chemical shifts of the methylene signal $\delta_{\mathrm{H}} 1.65$ (sext, $J=7.0 \mathrm{~Hz}$ ) and $1.96(\mathrm{sext}, J=7.0 \mathrm{~Hz}) / \delta_{\mathrm{C}} 34.6$ were identified instead of one methine at C-3 of $\mathbf{1}$ (Table 1). On the basis of the COSY and HMBC data (Figure 2), compound 2 was postulated to be composed of an isoprenoid, one glucose, and the $n$-butyl groups as well. The HMBC ${ }^{3} J$ correlations of $\mathrm{H}_{2}-1$ " $\left(\delta 4.04,2 \mathrm{H}, \mathrm{t}, J=7.5 \mathrm{~Hz} / \delta_{\mathrm{C}} 65.4\right)$ with $\mathrm{C}-1(\delta 178.5)$

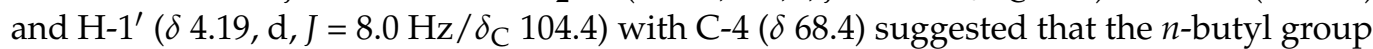
and one $\beta$-glucose moiety [8] were connected at C-1 and C-4, respectively (Figure 2). Key $\mathrm{HMBC}$ and COSY correlations are shown in Figure 2. The $R$-configuration of $\mathrm{H}_{3}-5$ at $\mathrm{C}-2$ of $\mathbf{2}$ was determined by acid hydrolysis of $\mathbf{2}$ to offer corresponding tulipalin compound, 3-methyldihydrofuran-2(3H)-one (Figure S28) [8] with a positive optical rotation value $\left([\alpha]^{23} \mathrm{D}+18.7, \mathrm{CH}_{2} \mathrm{Cl}_{2}\right)\left(R:[\alpha]^{25} \mathrm{D}+14.7, \mathrm{CHCl}_{3}\right)[10]$. The structure of compound 2 was identified as butyl $4-\beta$-D-glycopyranosyl- $(R)-2$-methylbutanoate.

The molecular formula of $\mathbf{3}$ was deduced as $\mathrm{C}_{11} \mathrm{H}_{20} \mathrm{O}_{8}$ due to the appearance of a [M $+\mathrm{Na}^{+}$ion at $m / z 303.1049$ (calcd for 303.1050) in the HRESIMS. Eleven carbon signals, including one methyl ( $\delta 17.6)$, three methylenes $(\delta 34.7,62.8$, and 68.6$)$, six methines $(\delta 37.6$, $71.6,75.1,77.9,78.0$, and 104.4), and one quaternary carbon $(\delta 180.6)$, were observed in the 1D NMR spectra of 3 (Table 1). The quaternary carbon was identified as a carbonyl carbon on the basis of the carbon chemical shift at $\delta$ 180.6. Furthermore, compound 3 showed similar spectroscopic data to that of 2, except the $n$-butyl signals. In the HMBC spectrum (Figure S15), the anomeric proton at $\delta 4.23(\mathrm{~d}, J=8.0 \mathrm{~Hz})$ exhibited ${ }^{3} \mathrm{~J}$ interaction with C-4 ( $\delta$ 68.6) led to the $\beta$-glucose located at C-4. Key HMBC and COSY connections are shown in Figure 2. Compound 3 was not isolated in a sufficient quantity to determine the absolute configuration at C-2. Finally, tuliposide J (3), 4- $\beta$-D-glycopyranosyl-(R)-2-methylbutanoic acid, was identified because of abovementioned structural elucidations of $\mathbf{1}$ and $\mathbf{2}$ in this study.

Compounds 1-3 are tuliposides, a kind of specialized products consisting of 4-hydroxy2-methylenebutanoic acid (HMBA) and/or (3S)-3,4-dihydroxy-2-methylenebutanoic acid (DHMBA) groups acylated at C- 1 and /or C-6 positions of a $\beta$-D-glucose (Glc) mainly found in the genus Tulipa [8,11]. So far, tuliposide analogues, including 1-tuliposide A, 6-tuliposide A, 1-tuliposide B, 6-tuliposide B, and tuliposides D-G, have been isolated from Tulipa $[8,11]$. However, the structure of tuliposide $C$ has not been reported and could be missing in previous literatures [11]. Tulipalins, such as tulipalin A and (-)-tulipalin B, are the aglycone portions of tuliposides, which spontaneously lactonizes after releasing HMBA and/or DHMBA groups by tuliposide-converting enzymes [8,11]. In this study, compounds 1-3 named as tuliposides $\mathrm{H}-\mathrm{J}$ belong to tuliposides, but their double bonds at C-2 were reduced and the $\beta$-D-glucose groups were attached to $\mathrm{C}-4$ (oxymethylene), instead of $\mathrm{C}-1$ (O-acyl functionality) in HMBA or DHMBA (Figure 1). Additionally, compound $\mathbf{1 0}(2 S, 3 S)$ is tulipalin but could not be metabolized from $1(2 R, 3 S)$ due to the different configuration at $C-2$. The possible biosyntheses of tuliposides 1-3 are shown in Figure S29 [8,11].

In addition, 11 known compounds including three pyroglutamic acid analogues (4-6), three citric acid derivatives (7-9), two furanones (10-11), one furan (12), and two steroids (13-14) were isolated from A. edulis for the first time. Compounds 1-9 and 1014 were obtained from TEB and TEE crude fractions, respectively. They were identified as (+)-pyroglutamic acid (4) [12], (+)-methyl 5-oxopyrrolidine-2-carboxylate (5) [12], (+)butyl 5-oxopyrrolidine-2-carboxylate (6) [12], 1-butyl citrate (7) [13], 1,1'-dibutyl 5-methyl citrate (8) [13], tributyl citrate (9) [13], (-)-3-hydroxy-2-methylbutyrolactone (10) [14-16], (-)methyl 3-hydroxy-5-oxotetrahydrofuran-3-carboxylate (11) [17], 5-(hydroxymethyl)furfural (12) [18], sitosterol (13) [19], and sitosterol-3- $\beta$-D-glucose (14) [20] from the spectroscopic data and compared with the literature. 


\subsection{Chemical Components Elucidation of TEW}

The ${ }^{1} \mathrm{H}$ and ${ }^{13} \mathrm{C}$ NMR spectra of TEW, a water-soluble crude fraction from TEM extract, showed very similar to that of carbohydrates (Figures S16 and S17). Polysaccharide prepared from this species have been reported to possess rhamnose, xylose, arabinose, galactose, mannose, glucose, and fructose after monosaccharide analysis [3,8]. The NMR spectroscopic data and the TLC (thin-layer chromatography) retention factor of TEW compared with those of the sugar standards (Figures S18-S23) suggested D-glucose and D-fructose were the main components in TEW extracts.

\subsection{Effects of Extracts and Isolates on Melanogenesis}

The MeOH extract (TEM) of this species was separated into TEE, TEB, and TEW crude fractions, and the aforementioned four extracts were evaluated for cytotoxicity and melanogenesis effects in B16 melanoma cells at concentrations from 12.5 to $200 \mu \mathrm{g} / \mathrm{mL}$ (Figure S24). TEE showed obvious cytotoxicity toward B16 at $200 \mu \mathrm{g} / \mathrm{mL}$ and TEB as well as TEW had cytotoxic activities at concentrations from 12.5 to $200 \mu \mathrm{g} / \mathrm{mL}$ (Figure S24A-1,B-1,C-1,D-1). In the bioassay, $\alpha$-melanocyte-stimulating hormone ( $\alpha$-MSH) was used to activate B16 cells to synthesize more melanin, and TEM could moderately stimulate melanogenesis (Figure S24A-2). Most of all isolates (Figure 1), excluding 13 and 14, were further assayed for the regulation of melanogenesis effects at concentrations from 10 to 40 $\mu \mathrm{M}$, with arbutin used as a positive control (Figure 4). As shown in Figure 4, compound 9 obviously and dose-dependently inhibited melanin production that resulted from cytotoxicity toward B16 cells with an $\mathrm{IC}_{50}$ (half maximal inhibitory concentration) value of $81.9 \mu \mathrm{M}$ (Figure S25). Isolates 4, 6, 10, and 12 increased melanin contents dose-dependently up to the maximum percentages of $11.9 \%, 29.8 \%, 27.2 \%$, and $17.6 \%$, respectively, at $40 \mu \mathrm{M}$ with no cellular toxicity. Tyrosinase plays a key role in the first two steps of melanogenesis [6]; therefore, the effects of compounds 4, 6, 10, and $\mathbf{1 2}$ on intracellular tyrosinase were further evaluated. $\alpha$-MSH increased the tyrosinase activity up to $254.3-305.5 \%$ when compared with the control group (100\%) (Figure 5 and Table S1). Consequently, 4 (14.1-21.9\%), 6 $(15.8-21.9 \%), \mathbf{1 0}(8.5-13.1 \%)$, and $\mathbf{1 2}(7.5-11.8 \%)$ moderately increased the activity of the enzyme, tyrosinase, in a dose-dependent manner at concentrations of 10 to $40 \mu \mathrm{M}$, while compared with the $\alpha$-MSH group (Figure 5 and Table S1). A correlation graph between the cellular melanin contents and the effects on the tyrosinase of compounds $4,6, \mathbf{1 0}$, and 12 is shown in Figure S26. Furthermore, to confirm the melanogenesis-inducing effects of 4, 6, 10, and 12, each compound was added in B16 cells without co-treated $\alpha-\mathrm{MSH}$ that was used as a positive control in this assay (Figure S27). Consequently, individual 4, 6, 10, and 12 did not increase melanin productions alone (Figure S27) similar to those shown in Figure 4, and it was suggested the abovementioned four compounds could merely enhance melanogenesis effects of $\alpha$-MSH. Accordingly, additional signal pathways in melanogenesis, such as tyrosinase-related protein-1 (TRP-1), TRP-2, microphthalmia-associated transcription factor, melanocortin 1 receptor, cyclic adenosine monophosphate, protein kinase A, cAMPresponse element-binding protein, c-Jun $\mathrm{N}$-terminal kinases, extracellular signal-regulated kinase, p38, and phosphoinositide 3-kinase/protein kinase B $[7,21]$, should be further tested and confirmed for those active components. 


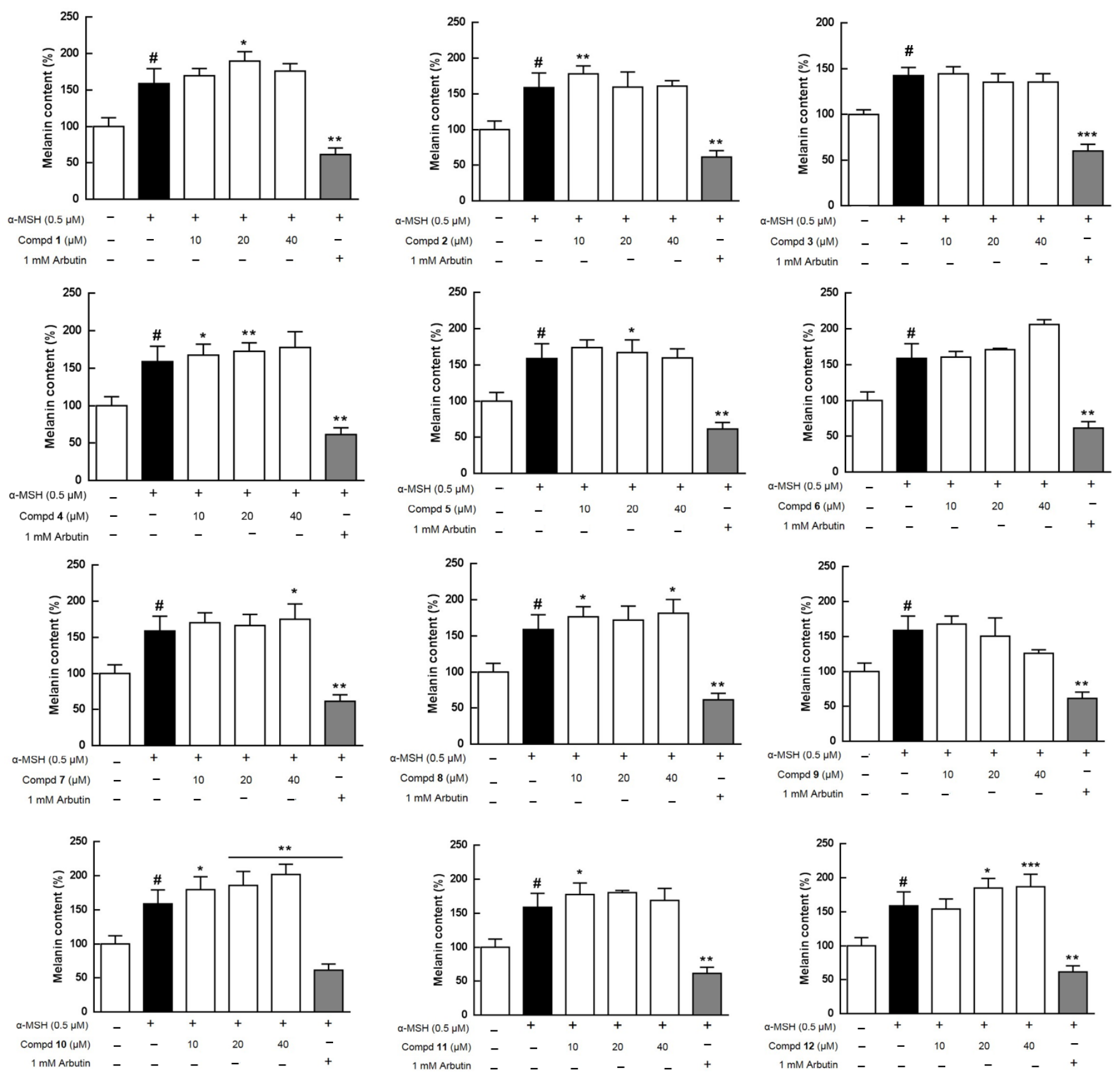

Figure 4. Regulation of melanogenesis effects of compounds 1-12. The data are representative of three independent experiments. \#, $p<0.05$ compared with the control group; ${ }^{*}, p<0.05,{ }^{* *}, p<0.01$, and ${ }^{* * *}, p<0.001$ compared with the $\alpha$-MSH-treated group. 

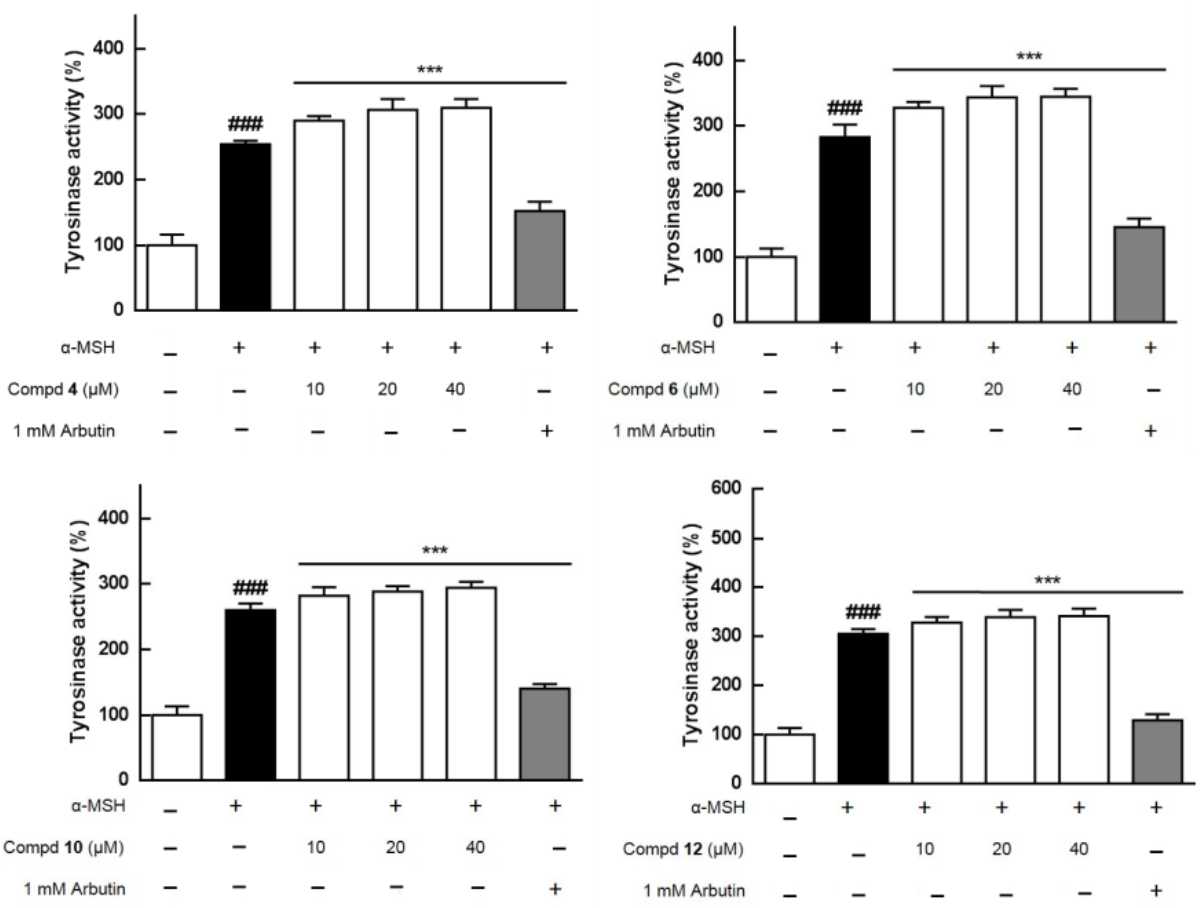

Figure 5. Tyrosinase activity effects of compounds 4-, 6-, 10-, and 12-treated B16 melanoma cells. \#\#\#, $p<0.05$ compared with the control group; ${ }^{* * *}, p<0.001$ compared with the $\alpha$-MSH-treated group.

\section{Materials and Methods}

\subsection{General Experimental Procedures}

NMR spectra were measured on a Bruker Avance III $500 \mathrm{MHz}$ instrument (Bruker, Billerica, America) for ${ }^{1} \mathrm{H}$ and $125 \mathrm{MHz}$ for ${ }^{13} \mathrm{C}-\mathrm{NMR}$. Chemical shift $(\delta)$ values were in ppm, and coupling constants $(J)$ were in $\mathrm{Hz}$ with $\mathrm{CD}_{3} \mathrm{OD}, \mathrm{CDCl}_{3}$, and /or $\mathrm{D}_{2} \mathrm{O}$ used as solvents. Optical rotations were obtained on a JASCO-P-2000 polarimeter (JASCO, Tokyo, Japan) (cell length $10 \mathrm{~mm}$ ). IR spectra were recorded on a PerkinElmer Spectrum Two FT-IR spectrometer (PerkinElmer, Waltham, MA, USA). Low- and high-resolution ESIMS (electrospray ionization mass spectrometry) were measured on a Bruker Daltonics Esquire HCT ultra high capacity trap mass spectrometer and an Orbitrap mass spectrometer (LTQ Orbitrap XL, Thermo Fisher Scientific), respectively. TLC was performed on Kieselgel $60 \mathrm{~F}_{254}$ (0.25 mm; Merck) and/or RP- $18 \mathrm{~F}_{254} \mathrm{~S}$ (0.25 mm; Merck), coated plates and then stained by spraying with $5 \%(v / v)$ sulfuric acid in a $\mathrm{MeOH}$ solution and heating on a hot plate. Silica gel (Silicycle: 70-230 and 230-400 mesh), RP-18 (LiChroprep ${ }^{\circledR} 40$ $63 \mu \mathrm{m}$; Merck), Sephadex ${ }^{\mathrm{TM}}$ LH-20 (GE Healthcare, Uppsala, Sweden), Diaion ${ }^{\circledR}$ HP-20 (Supelco $^{\mathrm{TM}}$, Bellefonte), and $\mathrm{MCI}^{\circledR}$ CHP20P (Supelco ${ }^{\mathrm{TM}}$, Bellefonte) were applied for column chromatography. A Shimadzu LC-20AT pump and a Shimadzu RID-10A refractive index detector (Shimadzu Inc., Kyoto, Japan), along with a Cosmosil 5 $\mathrm{C}_{18}$-MS-II (250 $\times$ $10 \mathrm{~mm}$ i.d., $5 \mu \mathrm{m}$ ) column at a flow rate of $2.0 \mathrm{~mL} / \mathrm{min}$, were used for HPLC. Sugar reagents, including D-glucose (MP Biomedicals, LLC, Illkirch, France) and D-fructose (TCI, Tokyo, Japan) were used for water-soluble crude fraction (TEW) analysis.

\subsection{Plant Material}

Dry bulbs of A. edulis (formerly T. edulis) were purchased from a traditional Chinese medicine pharmacy in Taichung, Taiwan, in September 2018 and identified by the author, Prof. Chang. A voucher specimen (TE201809) was deposited at the Chinese Medicine Research and Development Center, CMUH, Taiwan. 


\subsection{Extraction and Isolation}

The bulbs of $A$. edulis $(5.0 \mathrm{~kg}$ ) were extracted eight times with $\mathrm{MeOH}(8.0 \mathrm{~L}$ each) at room temperature to obtain a crude extract. The $\mathrm{MeOH}$ extract (TEM, 525.0 g) was partitioned three times between ethyl acetate (EtOAc) and $\mathrm{H}_{2} \mathrm{O}(1500: 1500, v / v)$ to give an EtOAc-soluble fraction (TEE, $45.0 \mathrm{~g}$ ) and an aqueous phase, which was further partitioned with $n-\mathrm{BuOH} / \mathrm{H}_{2} \mathrm{O}(1500: 1500, v / v \times 3)$, and then separated into $n-\mathrm{BuOH}$-soluble (TEB, $53.6 \mathrm{~g}$ ) and $\mathrm{H}_{2} \mathrm{O}$-soluble (TEW, $410.0 \mathrm{~g}$ ) fractions.

TEE was subjected to open column chromatography on a silica gel $(0.063-0.200 \mathrm{~mm}$, column: $7 \times 26 \mathrm{~cm}$, diameter $\times$ length), using gradients of hexane-EtOAc-MeOH (30:1:0; 1:1:0; 0:0:1, $v / v / v)$ and gave 14 subfractions (TEE1-TEE14). Precipitate $14(249.0 \mathrm{mg}$; isolation yield: $0.00498 \%)$ obtained from subfraction TEE12 $(2.2 \mathrm{~g})$ was filtered and washed with MeOH. TEE9 (3.6 g) was fractionated into seven subfractions (TEE9-1 to 9-7) by silica gel (column: $5 \times 24 \mathrm{~cm} ; \mathrm{CH}_{2} \mathrm{Cl}_{2}-\mathrm{MeOH}, 7: 1 ; 1: 1 ; 0: 1, v / v$ ), with subfraction TEE9-4 $(1.1 \mathrm{~g})$, and then subjected to Sephadex LH-20 column chromatography (column: $5 \times 54$ $\mathrm{cm} ; \mathrm{CH}_{2} \mathrm{Cl}_{2}-\mathrm{MeOH}, 1: 1$ to $\left.0: 1, v / v\right)$, to give seven subfractions (TEE9-4-1 to 9-4-7). TEE94-5 and TEE9-4-6 were combined (total $551.7 \mathrm{mg}$ ) and repeatedly purified by RP-HPLC $\left(\mathrm{MeOH}-\mathrm{H}_{2} \mathrm{O}, 45: 55 ; 20: 80, v / v\right)$ to give $12\left(21.0 \mathrm{mg} ; t_{\mathrm{R}}=13 \mathrm{~min}\right.$; isolation yield: $\left.0.00042 \%\right)$ and a mother liquor $(131.2 \mathrm{mg})$, which was further subjected to RP-HPLC $\left(\mathrm{MeOH}-\mathrm{H}_{2} \mathrm{O}\right.$; $10: 90, v / v)$ to give compounds $10\left(35.5 \mathrm{mg} ; t_{\mathrm{R}}=13 \mathrm{~min}\right.$; isolation yield: $\left.0.00071 \%\right)$ and 11 $\left(1.2 \mathrm{mg} ; t_{\mathrm{R}}=15 \mathrm{~min}\right.$; isolation yield: $\left.0.000024 \%\right)$. Fraction TEE6 $(2.7 \mathrm{~g})$ was isolated by Sephadex LH-20 (column: $\left.2.5 \times 45 \mathrm{~cm} ; \mathrm{CH}_{2} \mathrm{Cl}_{2}-\mathrm{MeOH}, 1: 1 ; 0: 1, v / v\right)$ to get 13 (6.8 mg; isolation yield: $0.000136 \%$ ).

TEB was chromatographed over a Diaion HP-20 column $\left(6 \times 60 \mathrm{~cm} ; \mathrm{H}_{2} \mathrm{O}-\mathrm{MeOH}-\right.$ acetone, 100:0:0; 25:75:0; 50:50:0; 75:25:0; 0:100:0; 0:0:100, $v / v / v)$ to give six subfractions (TEB1-TEB6). Subfraction TEB5 (502.0 mg) was purified by RP-HPLC $\left(\mathrm{MeOH}-\mathrm{H}_{2} \mathrm{O}, 85: 15\right.$, $v / v)$ to obtain compounds $8\left(9.3 \mathrm{mg} ; t_{\mathrm{R}}=10 \mathrm{~min}\right.$; isolation yield: $\left.0.000186 \%\right)$ and $9(144.2$ $\mathrm{mg} ; t_{\mathrm{R}}=15 \mathrm{~min}$; isolation yield: $0.002884 \%$ ). Fraction TEB3 (5.5 g) was subjected to RP-18 chromatography (column: $7 \times 25 \mathrm{~cm} ; \mathrm{MeOH}-\mathrm{H}_{2} \mathrm{O}, 1: 1 ; 1: 0, v / v$ ), and subfraction TEB3-6 $(1.0 \mathrm{~g})$ was further isolated by Sephadex LH-20 (column: $5 \times 54 \mathrm{~cm}$; MeOH) to obtain seven subfractions (TEB3-6-1 to 3-6-7). TEB3-6-4 (377.1 mg) was separated by MCI gel chromatography (column: $2.5 \times 23 \mathrm{~cm} ; \mathrm{H}_{2} \mathrm{O}-\mathrm{MeOH}, 100: 0 ; 80: 20 ; 60: 40 ; 40: 60 ; 20: 80 ; 0: 100$, $v / v$ ) to give seven subfractions (TEB3-6-4-1 to 3-6-4-7). TEB3-6-4-4 (38.1 mg) was purified by RP-HPLC (MeOH- $\mathrm{H}_{2} \mathrm{O}, 45: 55$ in $0.1 \%$ formic acid, $\left.v / v\right)$ to afford pure $\mathbf{1}\left(12.2 \mathrm{mg} ; t_{\mathrm{R}}=17\right.$ min; isolation yield: 0.000244\%). Additionally, TEB3-6-4-6 (31.0 mg) was conducted with RP-HPLC (MeOH- $\mathrm{H}_{2} \mathrm{O}, 40: 60$ in 0.1\% formic acid, $\left.v / v\right)$ to yield $6\left(7.1 \mathrm{mg} ; t_{\mathrm{R}}=28 \mathrm{~min}\right.$; isolation yield: $0.000142 \%)$. TEB3-6-5 (410.7 $\mathrm{mg})$ was isolated by MCI gel chromatography (column: $2.5 \times 23 \mathrm{~cm} ; \mathrm{H}_{2} \mathrm{O}-\mathrm{MeOH}, 100: 0 ; 80: 20 ; 60: 40 ; 50: 50 ; 40: 60 ; 30: 70 ; 20: 80 ; 0: 100, v / v$ ) to give eight subfractions (TEB3-6-5-1 to 3-6-5-8). TEB3-6-5-3 (75.1 $\mathrm{mg}$ ) was purified by MCI gel chromatography (column: $1 \times 20 \mathrm{~cm} ; \mathrm{H}_{2} \mathrm{O}-\mathrm{MeOH}, 80: 20 ; 70: 30 ; 0: 100, v / v$ ) to afford compounds 4 (59.3 mg; isolation yield: $0.001186 \%)$ and $5(10.2 \mathrm{mg}$; isolation yield: 0.000204\%). Subfraction TEB3-6-5-4 (97.0 mg) was purified by RP-HPLC $\left(\mathrm{MeOH}-\mathrm{H}_{2} \mathrm{O}\right.$, $40: 60 \mathrm{in} 0.1 \%$ formic acid, $v / v)$ to obtain 7 (46.4 mg; $t_{\mathrm{R}}=18 \mathrm{~min}$; isolation yield: $0.000928 \%$ ). TEB3-10 (925.4 mg) was chromatographed over an MCI gel chromatography (column: 2.5 $\left.\times 28 \mathrm{~cm} ; \mathrm{H}_{2} \mathrm{O}-\mathrm{MeOH}, 100: 0 ; 80: 20 ; 60: 40 ; 50: 50 ; 40: 60 ; 30: 70 ; 10: 90 ; 0: 100, v / v\right)$ to give eight subfractions (TEB3-10-1 to 3-10-8) and pure 2 (393.4 mg; isolation yield: $0.007868 \%$ ). Compound 3 ( $6.3 \mathrm{mg} ; t_{\mathrm{R}}=8 \mathrm{~min}$; isolation yield: $0.000126 \%$ ) was obtained from TEB3-10-2 (20.9 mg) by RP-HPLC purification ( $\mathrm{MeOH}-\mathrm{H}_{2} \mathrm{O}, 30: 70$ in $0.1 \%$ formic acid, $v / v$ ).

\subsubsection{Tuliposide $\mathrm{H}(\mathbf{1})$}

$[\alpha]^{23} \mathrm{D}-23.1$ (c 0.12, MeOH); IR (neat) $v_{\max } 3376(\mathrm{OH}), 2960,2934,2875(\mathrm{CH}), 1725$ $(\mathrm{C}=\mathrm{O}), 1640,1589,1459,1382,1259,1167,1075,1041(\mathrm{C}-\mathrm{O}-\mathrm{C}), 926,900,632,521 \mathrm{~cm}^{-1} ;{ }^{1} \mathrm{H}$ and ${ }^{13} \mathrm{C}$ NMR spectroscopic data, see Table 1; HRESIMS $m / z 351.1652[\mathrm{M}-\mathrm{H}]^{-}($calcd for $\left.\mathrm{C}_{15} \mathrm{H}_{27} \mathrm{O}_{9}, 351.1655\right)$. 


\subsubsection{Tuliposide I (2)}

$[\alpha]^{23} \mathrm{D}-25.8\left(c\right.$ 0.2, MeOH); IR (neat) $v_{\max } 3404(\mathrm{OH}), 2961,2934,2876(\mathrm{CH}), 1729$ $(\mathrm{C}=\mathrm{O}), 1638,1461,1378,1277,1185,1165,1077,1036(\mathrm{C}-\mathrm{O}-\mathrm{C}), 897,736,625,517 \mathrm{~cm}^{-1} ;{ }^{1} \mathrm{H}$ and ${ }^{13} \mathrm{C}$ NMR spectroscopic data, see Table 1 ; HRESIMS $m / z 359.1686[\mathrm{M}+\mathrm{Na}]^{+}$(calcd for $\mathrm{C}_{15} \mathrm{H}_{28} \mathrm{O}_{8} \mathrm{Na}$, 359.1682).

\subsubsection{Tuliposide J (3)}

$[\alpha]^{23} \mathrm{D}+9.0\left(c\right.$ 0.1, MeOH); IR (neat) $v_{\max } 3424(\mathrm{OH}), 2953,2924,2853(\mathrm{CH}), 1740(\mathrm{C}=\mathrm{O})$, $1632,1441,1401$ (C-O-C), 1284, 1205, 1182, 1120, 1078, 1039, 893, 768, $721 \mathrm{~cm}^{-1} ;{ }^{1} \mathrm{H}$ and ${ }^{13} \mathrm{C}$ NMR spectroscopic data, see Table 1 ; HRESIMS $m / z 303.1049[\mathrm{M}+\mathrm{Na}]^{+}$(calcd for $\left.\mathrm{C}_{11} \mathrm{H}_{20} \mathrm{O}_{8} \mathrm{Na}, 303.1050\right)$.

\section{4. (R)- and (S)-MTPA Derivatives of $\mathbf{1}$}

The preparation of the (S)-MTPA ester derivative of $\mathbf{1}$ was carried out by a convenient Mosher ester procedure [22,23]. Compound $\mathbf{1}(3.4 \mathrm{mg}, 0.01 \mathrm{mmole})$ was transferred into a clean NMR tube and then dried completely under vacuum before being full of nitrogen. Furthermore, $\mathrm{C}_{5} \mathrm{D}_{5} \mathrm{~N}(0.5 \mathrm{~mL})$ and $(R)-(-)$ - $\alpha$-methoxy- $\alpha$-(trifluoromethyl)-phenyl-acetyl chloride (MTPA chloride, $12.2 \mathrm{mg}, 0.05$ mmole) were added immediately into the sealed NMR tube that was further shaken carefully to mix the sample and MTPA chloride. The ${ }^{1} \mathrm{H}$ NMR and ${ }^{1} \mathrm{H}^{1} \mathrm{H}$ COSY spectra of the mixture after reacting for $24 \mathrm{~h}$ at room temperature were recorded. The (R)-MTPA ester of $\mathbf{1}$ was also prepared similarly by the aforementioned process. Compound 1: $1 \mathrm{H}$ NMR $\left(\mathrm{C}_{5} \mathrm{D}_{5} \mathrm{~N}, 500 \mathrm{MHz}\right) \delta 0.78\left(\mathrm{H}-4^{\prime \prime}, \mathrm{t}\right), 1.26\left(\mathrm{H}-3^{\prime \prime}\right.$, sext), 1.28 (H3-5, d), 1.52 (H-2' , quint), 3.08 (H-2, quint), 3.95 (H-5', m), 4.03 (H-4a, dd), 4.05 (H-2',

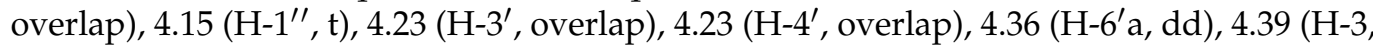
overlap), $4.43(\mathrm{H}-4 \mathrm{~b}, \mathrm{dd}), 4.53\left(\mathrm{H}-6^{\prime} \mathrm{b}, \mathrm{d}\right)$, and $4.95\left(\mathrm{H}-\mathrm{1}^{\prime}, \mathrm{d}\right)$.

\subsection{1. (S)-MTPA Ester of $\mathbf{1}$ (1a)}

${ }^{1} \mathrm{H}$ NMR $\left(\mathrm{C}_{5} \mathrm{D}_{5} \mathrm{~N}, 500 \mathrm{MHz}\right) \delta 0.77\left(\mathrm{H}-4^{\prime \prime}, \mathrm{t}\right), 1.17\left(\mathrm{H}-3^{\prime \prime}\right.$, sext), $1.21(\mathrm{H} 3-5, \mathrm{~d}), 1.37$ (H-2', quint), 3.18 (H-2, quint), $3.92\left(\mathrm{H}-\mathrm{-}^{\prime \prime}, \mathrm{t}\right), 3.97$ (H-4a, dd), $4.33\left(\mathrm{H}-5^{\prime}, \mathrm{m}\right), 4.39$ (H-3', t), 4.49 (H-4b, brd), $4.64\left(\mathrm{H}-6^{\prime} \mathrm{a}, \mathrm{dd}\right), 4.96\left(\mathrm{H}-1^{\prime}, \mathrm{d}\right), 5.05\left(\mathrm{H}-6^{\prime} \mathrm{b}, \mathrm{d}\right), 5.70\left(\mathrm{H}-2^{\prime}, \mathrm{t}\right), 5.76\left(\mathrm{H}-4^{\prime}, \mathrm{t}\right)$, and $5.82(\mathrm{H}-3, \mathrm{~m})$.

\subsection{2. (R)-MTPA Ester of $\mathbf{1}(\mathbf{1 b})$}

${ }^{1} \mathrm{H}$ NMR $\left(\mathrm{C}_{5} \mathrm{D}_{5} \mathrm{~N}, 500 \mathrm{MHz}\right) \delta 0.79\left(\mathrm{H}-4^{\prime \prime}, \mathrm{t}\right), 1.26\left(\mathrm{H}-3^{\prime \prime}\right.$, sext), $1.30(\mathrm{H} 3-5, \mathrm{~d}), 1.50$ (H-2', quint), 3.33 (H-2, quint), $3.60\left(\mathrm{H}-5^{\prime}, \mathrm{m}\right), 3.94$ (H-4a, dd), $4.11\left(\mathrm{H}-1^{\prime \prime}, \mathrm{t}\right), 4.12\left(\mathrm{H}-3^{\prime}, \mathrm{t}\right)$, $4.13\left(\mathrm{H}-6^{\prime} \mathrm{a}, \mathrm{dd}\right), 4.50(\mathrm{H}-4 \mathrm{~b}, \mathrm{brd}), 4.70\left(\mathrm{H}^{\prime} \mathbf{1}^{\prime}, \mathrm{d}\right), 4.85\left(\mathrm{H}-6^{\prime} \mathrm{b}, \mathrm{d}\right), 5.56\left(\mathrm{H}-2^{\prime}, \mathrm{t}\right), 5.66\left(\mathrm{H}-4^{\prime}, \mathrm{t}\right)$, and $5.81(\mathrm{H}-3, \mathrm{~m})$.

\subsection{Acid Hydrolysis of Tuliposide I (2)}

Isolate $2(78.6 \mathrm{mg})$ was hydrolyzed in $1 \mathrm{M} \mathrm{HCl}(1.5 \mathrm{~mL})$ at $100{ }^{\circ} \mathrm{C}$ for $2 \mathrm{~h}$ [8]. After cooling, the reaction mixture was extracted with $\mathrm{CH}_{2} \mathrm{Cl}_{2}(2.0 \mathrm{~mL} \times 3)$ to offer tulipalin analogue, 3-methyldihydrofuran-2(3H)-one (11.1 mg). $[\alpha]^{23} \mathrm{D}+18.7\left(c 1.1, \mathrm{CH}_{2} \mathrm{Cl}_{2}\right) ;{ }^{1} \mathrm{H}$ $\operatorname{NMR}\left(\mathrm{CDCl}_{3}, 400 \mathrm{MHz}\right) \delta 1.30(3 \mathrm{H}, \mathrm{d}, J=7.0 \mathrm{~Hz}), 1.94(\mathrm{~m}), 2.45(\mathrm{~m}), 2.61(\mathrm{~m}), 4.20(\mathrm{ddd}$, $J=8.8,6.8,6.4 \mathrm{~Hz}), 4.33(\mathrm{ddd}, J=8.8,8.8,2.8 \mathrm{~Hz}) .{ }^{13} \mathrm{C} \mathrm{NMR}\left(\mathrm{CDCl}_{3}, 100 \mathrm{MHz}\right) \delta 15.2,30.7$, 34.1, 66.2, 180.1 (Figure S28); ESIMS $m / z$ 101.06 $[\mathrm{M}+\mathrm{H}]^{+}$.

\subsection{Cell Culture}

The murine B16 melanoma cells were cultured in Dulbecco's Modified Eagle Medium (DMEM; GIBCO Invitrogen corporation, New York, NY, USA) supplemented with 10\% fetal bovine serum, $100 \mathrm{U} / \mathrm{mL}$ of penicillin, and $100 \mu \mathrm{g} / \mathrm{mL}$ of streptomycin at $37^{\circ} \mathrm{C}$ in a $5 \% \mathrm{CO}_{2}$ incubator. 


\subsection{Measurement of B16 Cell Viability}

The cytotoxicity of B16 cells for the test compounds was measured by MTT with a previously described protocol with slight modifications [6]. The cells were seeded in 96-well plates $\left(1 \times 10^{3}\right.$ cells/well) and cultured for $24 \mathrm{~h}$ before treated with compounds for other $72 \mathrm{~h}$. After that, the medium was removed, $100 \mu \mathrm{L}$ of MTT reagent (Thermo Scientific, Waltham, MA, USA) (at the final concentration of $0.5 \mathrm{mg} / \mathrm{mL}$ ) was added to each well and then incubated at $37^{\circ} \mathrm{C}$ for $1 \mathrm{~h}$. The formazan crystal was dissolved in $100 \mu \mathrm{L}$ DMSO, and the optical density was measured by using a microplate reader (SPECTORstar ${ }^{\circledR}$ Nano, BMG LABTECH, Ortenberg, Germany) at $570 \mathrm{~nm}$.

\subsection{Measurement of Melanin Content in B16 Cells}

The melanin content in B16 cells was assayed according to a previously described method with slight modifications [6]. The cells were seeded at a density of $5 \times 10^{3}$ cells/well in 24-well plates for $24 \mathrm{~h}$. The medium was replaced by a $500 \mu \mathrm{L}$ fresh culture medium containing $0.5 \mu \mathrm{M} \alpha-\mathrm{MSH}$ with or without compounds for $72 \mathrm{~h}$. Arbutin (1 mM) was used as the positive control. After that, the medium was removed and washed by PBS ( $\mathrm{pH}$ 6.8) twice. The cells were harvested by $\mathrm{NaOH}(200 \mu \mathrm{L}, 2 \mathrm{~N})$ and then heated at $85^{\circ} \mathrm{C}$ for $30 \mathrm{~min}$. After cooling to room temperature and being centrifuged, the absorbance was measured at $405 \mathrm{~nm}$ using a microplate reader.

\subsection{Intracellular Tyrosinase Activity}

Intracellular tyrosinase activity assay was performed by a slightly modified method, which was reported previously [6]. The cells were seeded in 24-well plates at a density of 5 $\times 10^{3}$ cells $/$ well for $24 \mathrm{~h}$. The cells were treated in DMEM containing $0.5 \mu \mathrm{M} \alpha$-MSH with or without compounds for $72 \mathrm{~h}$. After removing the medium, the cells were washed by cold PBS (pH 6.8) twice. The cells were lysed by $100 \mu \mathrm{L}$ lysis buffer (1\% triton X-100 in PBS) and frozen at $-80^{\circ} \mathrm{C}$ for $15 \mathrm{~min}$. Then, the cell lysates were centrifuged at $13,200 \times \mathrm{g}$ at $4{ }^{\circ} \mathrm{C}$ for $30 \mathrm{~min}$ to obtain the supernatant. The total protein content of the supernatant was quantified by BCA protein assay. Next, each quantified lysate $(30 \mu \mathrm{g} / 90 \mu \mathrm{L})$ was mixed with $10 \mu \mathrm{L}$ of L-DOPA $(15 \mathrm{mM})$ in a 96-well plate and then incubated at $37^{\circ} \mathrm{C}$ for $1 \mathrm{~h}$, and the absorbance was measured at $405 \mathrm{~nm}$ using a microplate reader.

\section{Conclusions}

Overall, 14 pure compounds, including three new isoprenoid glycosides, tuliposides H-J (1-3), were isolated from A. edulis. Citric acid derivative 9, tributyl citrate, had significantly anti-melanogenesis activity but showed cytotoxicity toward B16 melanoma cell that could be further researched for anti-melanoma drugs. While pyroglutamic acid analogues 4 and 6, furanone 10, and furan 12 had dose-dependently increased melanin contents and activated tyrosinase that could be further studied for vitiligo skin disease or anti-whitening and anti-hypopigmentation agents for hair. However, in vitro mechanisms and/or in vivo studies are needed to be investigated in more detail to verify the efficacy of the active components.

Supplementary Materials: The following are available online, Figures S1-S5: NMR spectral data of compound 1, Figures S6-S10: NMR spectral data of compound 2, Figures S11-S15: NMR spectral data of compound 3, Figures S16-S22: NMR spectral data of TEW, Figure S23: TLC analysis of TEW, Figure S24: Cytotoxicity and the regulation of melanogenesis effects of TEM, TEE, TEB, and TEW, Figure S25: Cytotoxicity data of compounds 1-12, Figure S26: A correlation graph between the cellular melanin contents and the effects on tyrosinase of compounds 4, 6, 10, and 12, Figure S27: Melanogenesis effects of compounds 4, 6, 10, and 12 alone without $\alpha-M S H$, Figure S28: NMR spectral and optical rotation data of the product obtained from acid hydrolysis of compound 2, Figure S29: Possible biosynthesis of compounds 1-3, Table S1: Tyrosinase activity effects of compounds 4, 6, 10, and $\mathbf{1 2}$. 
Author Contributions: Conceptualization, C.-L.L.; plant material identification, Y.-S.C.; conduct of isolation and purification, C.-L.L. and Z.-A.G.; conduct of the bioassays, Y.-L.J.; all spectral analysis and structure determination, C.-L.L. and C.-J.C.; writing of the original draft preparation, C.-L.L. All authors have read and agreed to the published version of the manuscript.

Funding: This research was funded by the Ministry of Science and Technology (MOST 108-2320-B039-035-) and China Medical University (CMU108-MF-84), Taiwan. The APC was funded by the "Chinese Medicine Research Center, China Medical University" from The Featured Areas Research Center Program within the framework of the Higher Education Sprout Project by the Ministry of Education (MOE) in Taiwan (CMRC-CHM-1).

Institutional Review Board Statement: Not applicable.

Informed Consent Statement: Not applicable.

Data Availability Statement: Not applicable.

Acknowledgments: This work was financially supported by the Ministry of Science and Technology (MOST 108-2320-B-039-035-) and China Medical University (CMU108-MF-84), Taiwan, as well as the "Chinese Medicine Research Center, China Medical University" from The Featured Areas Research Center Program within the framework of the Higher Education Sprout Project by the Ministry of Education (MOE) in Taiwan (CMRC-CHM-1) awarded to C.-L.L.

Conflicts of Interest: The authors declare no conflict of interest.

Sample Availability: Samples of the compounds 1-14 are available from the authors.

\section{References}

1. Lin, R.; Li, Z.; Lin, J.; Ye, J.; Cai, Q.; Chen, L.; Peng, J. Ethanolic extract of Tulipa edulis Bak induces apoptosis in SGC-7901 human gastric carcinoma cells via the mitochondrial signaling pathway. Oncol. Lett. 2015, 10, 2371-2377. [CrossRef] [PubMed]

2. Fan, Y.; Hou, X.; Guo, P.; Lv, X.; Zhao, L.; Wang, H.; Zhou, L.; Feng, Y. Extraction of Amana edulis induces liver cancer apoptosis. Evid.-Based Complement. Altern. Med. 2018, 2018, 3927075. [CrossRef] [PubMed]

3. Ji, Y.H.; Liao, A.M.; Huang, J.H.; Thakur, K.; Li, X.L.; Wei, Z.J. Physicochemical and antioxidant potential of polysaccharides sequentially extracted from Amana edulis. Int. J. Biol. Macromol. 2019, 131, 453-460. [CrossRef]

4. Ji, Y.H.; Liao, A.M.; Huang, J.H.; Thakur, K.; Li, X.L.; Wei, Z.J. The rheological properties and emulsifying behavior of polysaccharides sequentially extracted from Amana edulis. Int. J. Biol. Macromol. 2019, 137, 160-168. [CrossRef]

5. Cao, Y.Y.; Ji, Y.H.; Liao, A.M.; Huang, J.H.; Thakur, K.; Li, X.L.; Hu, F.; Zhang, J.G.; Wei, Z.J. Effects of sulfated, phosphorylated and carboxymethylated modifications on the antioxidant activities in-vitro of polysaccharides sequentially extracted from Amana edulis. Int. J. Biol. Macromol. 2020, 146, 887-896. [CrossRef]

6. Lai, K.Y.; Hu, H.C.; Chiang, H.M.; Liu, Y.J.; Yang, J.C.; Lin, Y.A.; Chen, C.J.; Chang, Y.S.; Lee, C.L. New diterpenes leojaponins G-L from Leonurus japonicus. Fitoterapia 2018, 130, 125-133. [CrossRef]

7. Ullah, S.; Chung, Y.C.; Hyun, C.G. Induction of melanogenesis by fosfomycin in B16F10 cells through the upregulation of P-JNK and P-p38 signaling pathways. Antibiotics 2020, 9, 172. [CrossRef] [PubMed]

8. Christensen, L.P.; Kristiansen, K. Isolation and quantification of tuliposides and tulipalins in tulips (Tulipa) by high-performance liquid chromatography. Contact Dermat. 1999, 40, 300-309. [CrossRef]

9. Tripathi, A.; Puddick, J.; Prinsep, M.R.; Lee, P.P.F.; Tan, L.T. Hantupeptins B and C, cytotoxic cyclodepsipeptides from the marine cyanobacterium Lyngbya majuscula. Phytochemistry 2010, 71, 307-311. [CrossRef]

10. Qabaja, G.; Wilent, J.E.; Benavides, A.R.; Bullard, G.E.; Petersen, K.S. Facile synthesis of versatile enantioenriched $\alpha$-substituted hydroxy esters through a Brønsted acid catalyzed kinetic resolution. Org. Lett. 2013, 15, 1266-1269. [CrossRef]

11. Nomura, T.; Kato, Y. Identification of tuliposide G, a novel glucoside ester-type tuliposide, and its distribution in tulip. Z. Naturforsch. C. J. Biosci. 2020, 75, 75-86. [CrossRef]

12. Gang, F.L.; Zhu, F.; Li, X.T.; Wei, J.L.; Wu, W.J.; Zhang, J.W. Synthesis and bioactivities evaluation of L-pyroglutamic acid analogues from natural product lead. Bioorg. Med. Chem. 2018, 26, 4644-4649. [CrossRef]

13. Vereshchagin, A.L.; Anikina, E.V.; Syrchina, A.I.; Lapin, M.F.; Azin, L.A.; Semenov, A.A. Chemical investigation of the bitter substances of the fruit of Lonicera caerulea. Chem. Nat. Compd. 1989, 25, 289-292. [CrossRef]

14. Jaime, C.; Ortuño, R.M.; Font, J. Di- and trisubstituted $\gamma$-lactones. Conformational study by molecular mechanics calculations and coupling constant analysis. J. Org. Chem. 1986, 51, 3946-3951. [CrossRef]

15. Larchevêque, M.; Henrot, S. Enantiomerically pure $\beta, \gamma$-epoxyesters from $\beta$-hydroxylactones: Synthesis of $\beta$-hydroxyesters and (-)-GABOB. Tetrahedron 1990, 46, 4277-4282. [CrossRef]

16. Jaime, C.; Segura, C.; Dinarés, I.; Font, J. Substituted $\gamma$-lactones with vicinal hydrogen atoms. Conformation study by MM2 calculations and coupling constant analysis. J. Org. Chem. 1993, 58, 154-158. [CrossRef] 
17. Mori, K.; Fukamatsu, K. A synthesis of (1R,5S)-(+)-frontalin from (S)-(-)-2-hydroxyparaconic acid. Liebigs Ann. Chem. 1992, 11, 1191-1193.

18. Miyazawa, M.; Anzai, J.; Fujioka, J.; Isikawa, Y. Insecticidal compounds against Drosophila melanogaster from Cornus officinalis Sieb. et Zucc. Nat. Prod. Res. 2003, 17, 337-339. [CrossRef] [PubMed]

19. Lee, C.L.; Wang, C.M.; Hu, H.C.; Yen, H.R.; Song, Y.C.; Yu, S.J.; Chen, C.J.; Li, W.C.; Wu, Y.C. Indole alkaloids indigodoles A-C from aerial parts of Strobilanthes cusia in the traditional Chinese medicine Qing Dai have anti-IL-17 properties. Phytochemistry 2019, 162, 39-46. [CrossRef] [PubMed]

20. Faizi, S.; Ali, M.; Saleem, R.; Irfanullah; Bibi, S. Complete ${ }^{1} \mathrm{H}$ - and ${ }^{13} \mathrm{C}-\mathrm{NMR}$ assignments of stigma-5-en-3-O- $\beta$-glucoside and its acetyl derivative. Magn. Reson. Chem. 2001, 39, 399-405. [CrossRef]

21. Kuo, Y.H.; Chen, C.C.; Wu, P.Y.; Wu, C.S.; Sung, P.J.; Lin, C.Y.; Chiang, H.M. N-(4-methoxyphenyl) caffeamide-induced melanogenesis inhibition mechanisms. BMC Complement. Altern. Med. 2017, 17, 71. [CrossRef] [PubMed]

22. Ohtani, I.; Kusumi, T.; Kashman, Y.; Kakisawa, H. High-field FT NMR application of Mosher's method. The absolute configurations of marine terpenoids. J. Am. Chem. Soc. 1991, 113, 4092-4096. [CrossRef]

23. Lee, C.L.; Chang, F.R.; Hsieh, P.W.; Chiang, M.Y.; Wu, C.C.; Huang, Z.Y.; Lan, Y.H.; Chen, M.; Lee, K.H.; Yen, H.F.; et al. Cytotoxic ent-abietane diterpenes from Gelonium aequoreum. Phytochemistry 2008, 69, 276-287. [CrossRef] [PubMed] 